\title{
A NEW SPECIES OF PAVANIA (ACARI: HETEROSTIGMATA: DOLICHOCYBIDAE) ASSOCIATED WITH SCARABAEUS TYPHON (COLEOPTERA: SCARABAEIDAE) FROM RUSSIA
}

\author{
Alexander A. Khaustov ${ }^{1 *}$ and Andrey V. Frolov ${ }^{2}$
}

\author{
${ }^{1} \mathrm{X}$-Bio Institute, Tyumen State University, Tyumen, Russia \\ ${ }^{2}$ Zoological Institute of the Russian Academy of Sciences, Saint Petersburg, Russia \\ *corresponding author; e-mail: alkhaustov@mail.ru
}

\begin{abstract}
A new species Pavania foliata sp.n. (Acari: Heterostigmata: Dolichocybidae), phoretic on dung beetle Scarabaeus typhon Fischer-Waldheim (Coleoptera: Scarabaeidae) from southwest Russia, is described. The updated key to the species of the genus Pavania is provided.
\end{abstract}

KEY WORDS: Systematics, phoresy, dung beetle, Palaearctic region, key.

DOI: 10.21684/0132-8077-2020-28-2-169-176

\section{INTRODUCTION}

Dolichocybidae - a small family of early-derivative heterostigmatic mites - currently includes 2 subfamilies, 6 genera and 56 species (Hajiqanbar and Khaustov 2010; Rahiminejad et al. 2011; Loghmani et al. 2013; Katlav et al. 2014, 2020; Bahramian et al. 2015; Mortazavi et al.2015; Sobhi et al. 2017; Khaustov and Frolov 2017, 2018a, b, 2020; Khaustov and Trach 2017, 2018; Khaustov 2017; Hajiqanbar et al. 2019). Little is known about the behavioral patterns of dolichocybid mites, but all of them are probably fungivorous (Rack 1967; Magowski 1988; Kaliszewski et al. 1995). Some species are important pests of edible mushrooms (Lan et al. 2017). However, most dolichocybid mites are associated with insects (mostly beetles), utilizing them for phoresy (Khaustov and Trach 2017). The genus Pavania Lombardini is the largest in the family and includes 33 species, described from Eurasia, Africa, South America and Australia (Khaustov and Frolov 2020; Katlav et al. 2020).

At present, only three species of Pavania have been reported from Russia, namely $P$. bembidii Khaustov, 2005, P. carabidophila Khaustov, 2005 and P. protracta Sevastianov, 1980 (Khaustov and Trach 2017; Khaustov and Frolov 2020). Pavania carabidophila and P. bembidii are phoretic on carabid beetles of the genus Bembidion (Coleoptera: Carabidae) (Khaustov 2005; Khaustov and Trach 2017). The third species, P. protracta, was collected from soil (Sevastianov 1980).

During a study of mites associated with scarab beetles, a new species of Pavania was recovered in the southwest of Russia; it was phoretic on scarab beetle Scarabaeus typhon Fischer-Waldheim. The aim of this paper is to describe this new species. Moreover, the updated key to the species of the genus Pavania is provided.

\section{MATERIALS AND METHODS}

The host beetles were collected in a sandy semi-desert area located along the Akhtuba River (a distributary of the Volga River), about $90 \mathrm{~km}$ upstream of the Volga Delta, Astrakhan Region, European Russia. The beetles were preserved in $96 \%$ ethanol prior to dissection. The mites were found attached to the membrane that connects the $1^{\text {st }}$ abdominal tergite and the metanotum. Collected mites were kept in $96 \%$ ethanol prior to being mounted in Hoyer's medium. Mite morphology was studied using a Carl Zeiss AxioImager A2 compound microscope with phase contrast and DIC objectives. Micrographs were taken with an AxioCam 506 color digital camera.

The terminology of the idiosoma and legs follows Lindquist (1986); the nomenclature of subcapitular setae follows Grandjean (1944). All measurements are given in micrometers $(\mu \mathrm{m})$ for the holotype and five paratypes (in parentheses). For leg chaetotaxy, the number of solenidia is given in parentheses.

\section{RESULTS}

Family Dolichocybidae Mahunka, 1970

Genus Pavania Lombardini, 1949

Type species: Pavania fusiformis Lombardini, 1949, by original designation.

\section{Pavania foliata sp.n.}

(Figs. 1-4)

Description. Female (Figs. 1-4). Body weakly sclerotized. Length of idiosoma 130 (130-135), width 82 (80-87).

Gnathosoma. Gnathosomal capsule, excluding palps, almost round, its length 28 (24-28), width 


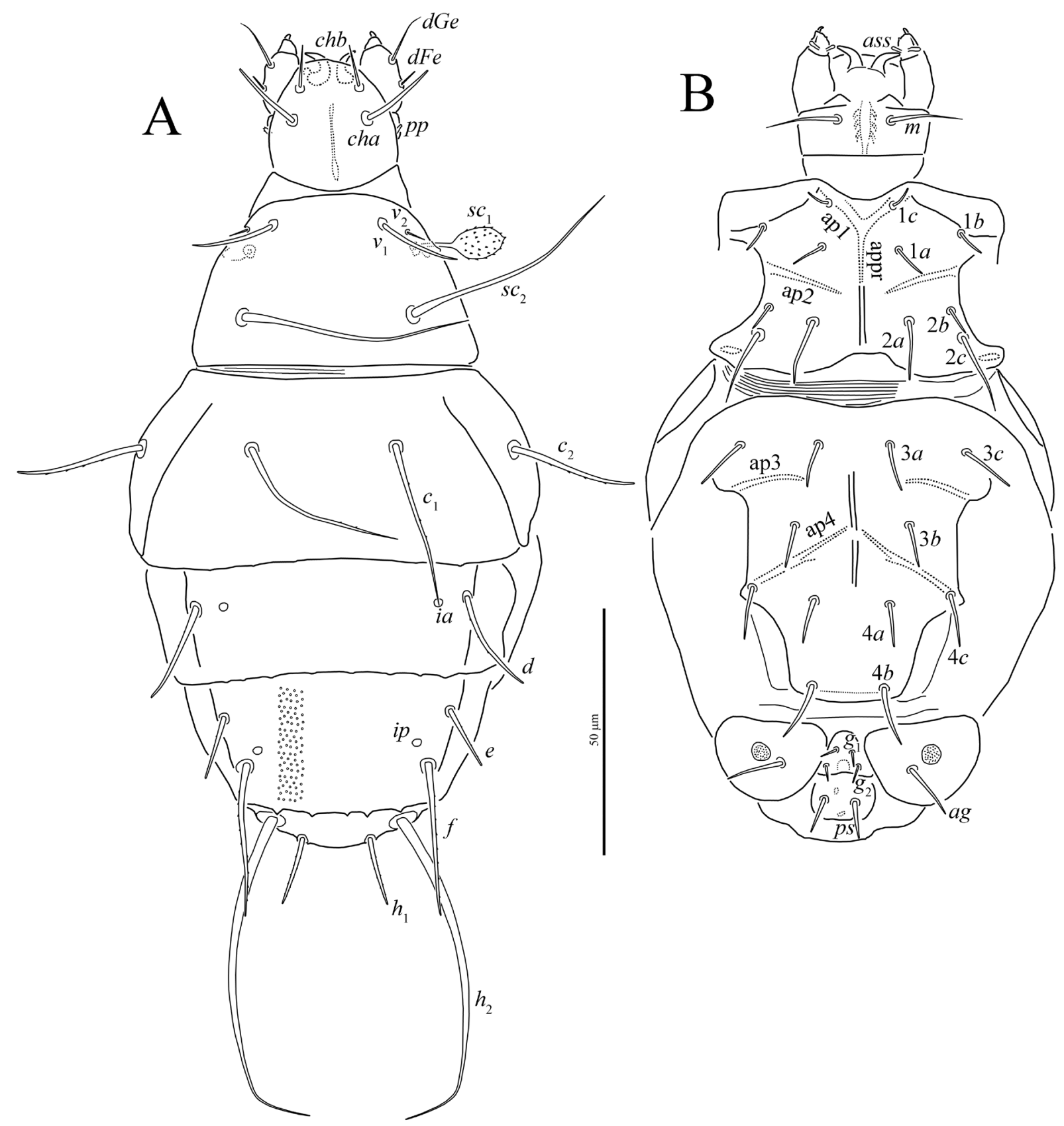

Fig. 1. Pavania foliata sp.n., female: A-dorsum of the body, B-venter of the body. Legs omitted.

27 (27-28). Dorsally with two pairs of blunt-ended and smooth cheliceral setae (cha, chb). Setae cha 15 (15-18) distinctly longer and thicker than chb 9 (9-10). Dorsal median apodeme weakly developed. Postpalpal setae $(p p)$ rod-like with tiny distal projections, situated posterolaterally to setae $c h a$. Venter of gnathosoma with one pair of smooth, pointed subcapitular setae $m 15$ (15-17). Palps freely articulated to gnathosomal capsule, with smooth setae $d F e$ and $d G e$ dorsolaterally, setae $d G e$ 10 (10-12) pointed, about two times longer than blunt-ended $d F e 5$ (4-5). Palps ventrally with so- lenidion and accessory setigenous structure subequal in length. Palps terminated with well-developed tibial claw. Palp tibiotarsus with tiny eupathidlike distal seta and small lateral seta. Cheliceral stylets strong, curved. Pharynx poorly visible, with at least three lateral projections.

Idiosomal dorsum (Figs. 1A, 4A). Tergite EF with clearly visible numerous round and very small dimples, other tergites smooth or with few poorly visible dimples. Prodorsal shield with three pairs of setae $\left(v_{1}, v_{2}, s c_{2}\right)$ and one pair of clavate, barbed trichobothria $s c_{1}$ with slightly attenuated apex. 


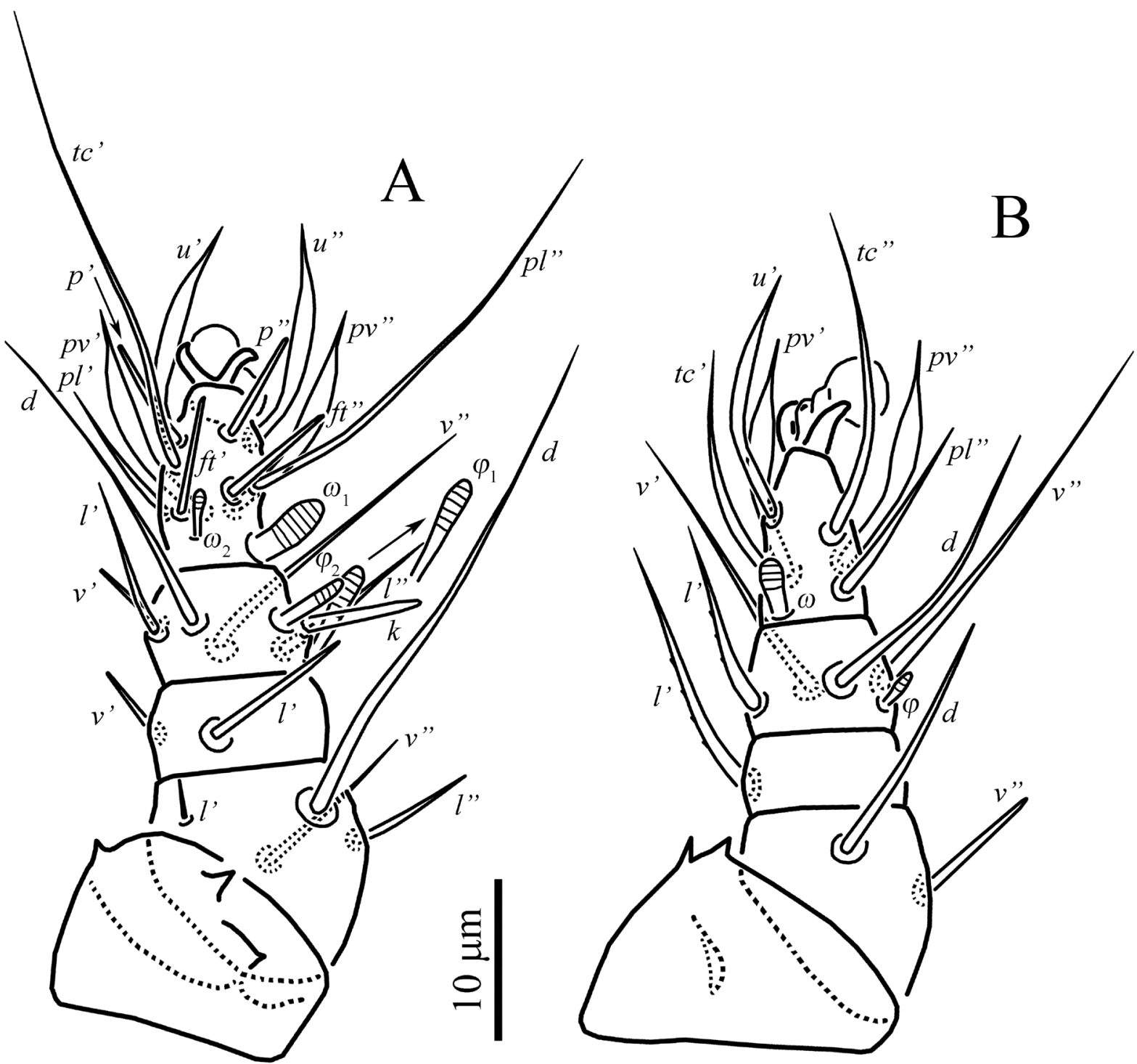

Fig. 2. Pavania foliata sp.n., female: A—right leg I in dorsal view, B-right leg II in dorsal view.

Setae $s c_{2}$ and $c_{1}$ pointed; other dorsal setae bluntended. Setae $c_{1}, c_{2}, d, f$ and $h_{1}$ weakly barbed, other dorsal setae smooth. Tips of setae $h_{2}$ not club-shaped. Cupules ia on tergite D and ip on tergite EF small, round; other cupules not evident. Posterior margins of tergites C, D and EF with several weak projections. Lengths of dorsal setae: $v_{1} 18(17-18), v_{2} 5(5-6), s c_{2} 49(48-50), c_{1} 37$ (35-37), $c_{2} 26(26-27), d 22(21-22), e 13(13-14)$, $f 32$ (32-34), $h_{1} 14$ (14-16), $h_{2} 69$ (66-70). Distances between setae: $v_{1}-v_{1} 23(23-24), v_{2}-v_{2} 32$ (32-33), $s c_{2}-s c_{2} 35$ (34-35), $c_{1}-c_{1} 29$ (29), $d-d 55$ (55-57), e-e 46 (45-46), f-f 37 (35-37), $h_{1}-h_{1} 14$ (13-14), $h_{1}-h_{2} 7$ (7-8).

Idiosomal venter (Figs. 1B, 4B). All ventral plates with very small sparsely distributed dimples
(Fig. 4B). All ventral setae smooth; setae $2 c$ pointed, other ventral setae blunt-ended. Apodemes 1 (ap1) and apodemes 2 (ap2) well developed and joined with short and poorly visible prosternal apodeme (appr), sejugal apodeme represented by pair of small sclerites located posterolaterad setae $2 c$; apodemes 3 (ap3) and 4 (ap4) well developed. Poststernal apodeme absent. Covisternal fields I-IV each with three pairs of setae. Lengths of ventral setae: $1 a 7$ (7-8), $1 b 6$ (6-7), 1c 5 (5-6), $2 a 12$ (12-14), $2 b 6$ (6-7), 2c 16 (16-20), $3 a 11$ (10-11), $3 b 9$ (9-10), 3c 12 (12-13), $4 a 9$ (9-10), $4 b 13$ (12-13), 4c 11 (11-13), ag 12 (12-13), g 3 (3-4), $g_{2} 4$ (4), ps 8 (8-9).

Legs (Figs. 2, 3). All legs subequal in length. Leg I (Fig. 2A). Setal formula: 0-4-2-6(2)-11(2). Tarsus 


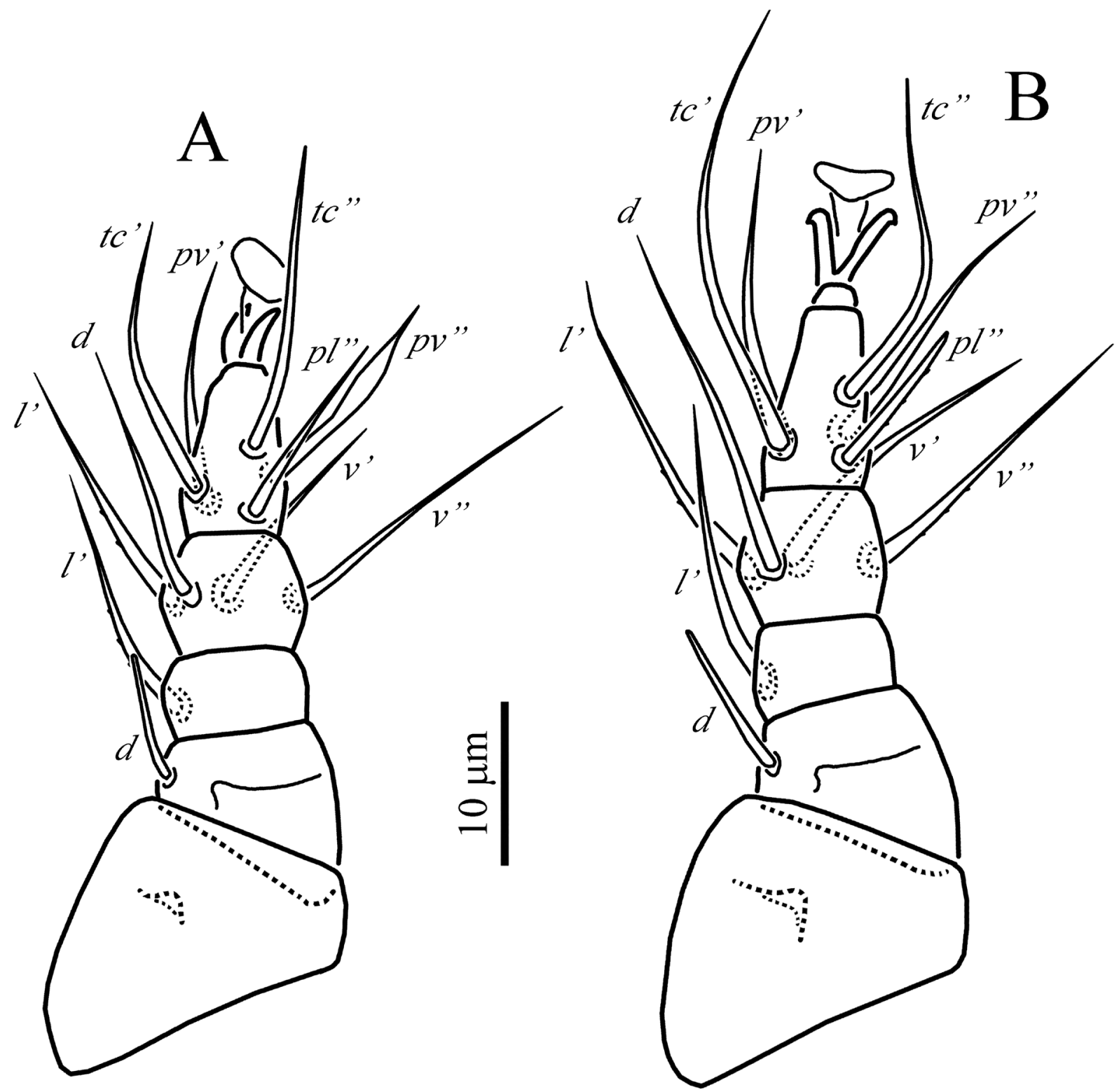

Fig. 3. Pavania foliata sp.n., female: A—right leg III in dorsal view, B—right leg IV in dorsal view.

with two small claws and semioval empodium. All leg setae smooth. Setae l', l', of femur, l' and v' of genu, $k$ and $v$ ' of tibia blunt-ended; other leg setae (except eupathidia $p^{\prime}, p$ ", $\left.f t^{\prime}, f t^{\prime \prime}\right)$ pointed; setae $(u)$ and $(p v)$ of tarsus clearly foliate in distal half. Trochanter dorsolaterally with three projections. Tarsus I with ventrodistal membranous flange. Lengths of solenidia $\omega_{1} 5$ (5-6), $\omega_{2} 3$ (3), $\varphi_{1} 7$ (7-8), $\varphi_{2} 5$ (5); solenidion $\varphi_{2}$ baculiform, solenidia $\omega_{2}$ and $\varphi_{1}$ weakly clavate, solenidion $\omega_{1}$ digitiform. Leg II (Fig. 2B). Setal formula: 0-2-1-4(1)-6(1). Tarsal claws simple, hooked; empodium large, extending beyond tips of claws. Solenidion $\omega 4$ (4) digitiform, solenidion $\varphi 3$ (3) weakly clavate. Trochanter dorsolaterally with two projections. Setae $d$ and $v$ " of femur weakly blunt-ended, other setae pointed; setae $u$ ' and $(p v)$ of tarsus clearly foliate in distal half. Setae $l$ ' of femur and genu weakly barbed, other setae smooth. Trochanter ventrally with short lobe. Leg III (Fig. 3A). Setal formula: 0-1-1-4-5. Claws and empodium of same shape as on tarsus II. Setae $d$ of femur bluntended, other leg setae pointed. Setae $l$ ' of genu and tibia weakly barbed; other leg setae smooth; seta $p v$ " clearly foliate in distal half. Trochanter ventrally with short lobe. Leg IV (Fig. 3B). Setal formula: 0-1-14-5. Claws and empodium of same shape as on tarsus III. Setae $d$ of femur and $p l$ " of tarsus bluntended, other leg setae pointed. Setae $l$, $v$ " of tibia and $p l$ " of tarsus weakly barbed; other leg setae smooth. Trochanter ventrally with short lobe. 


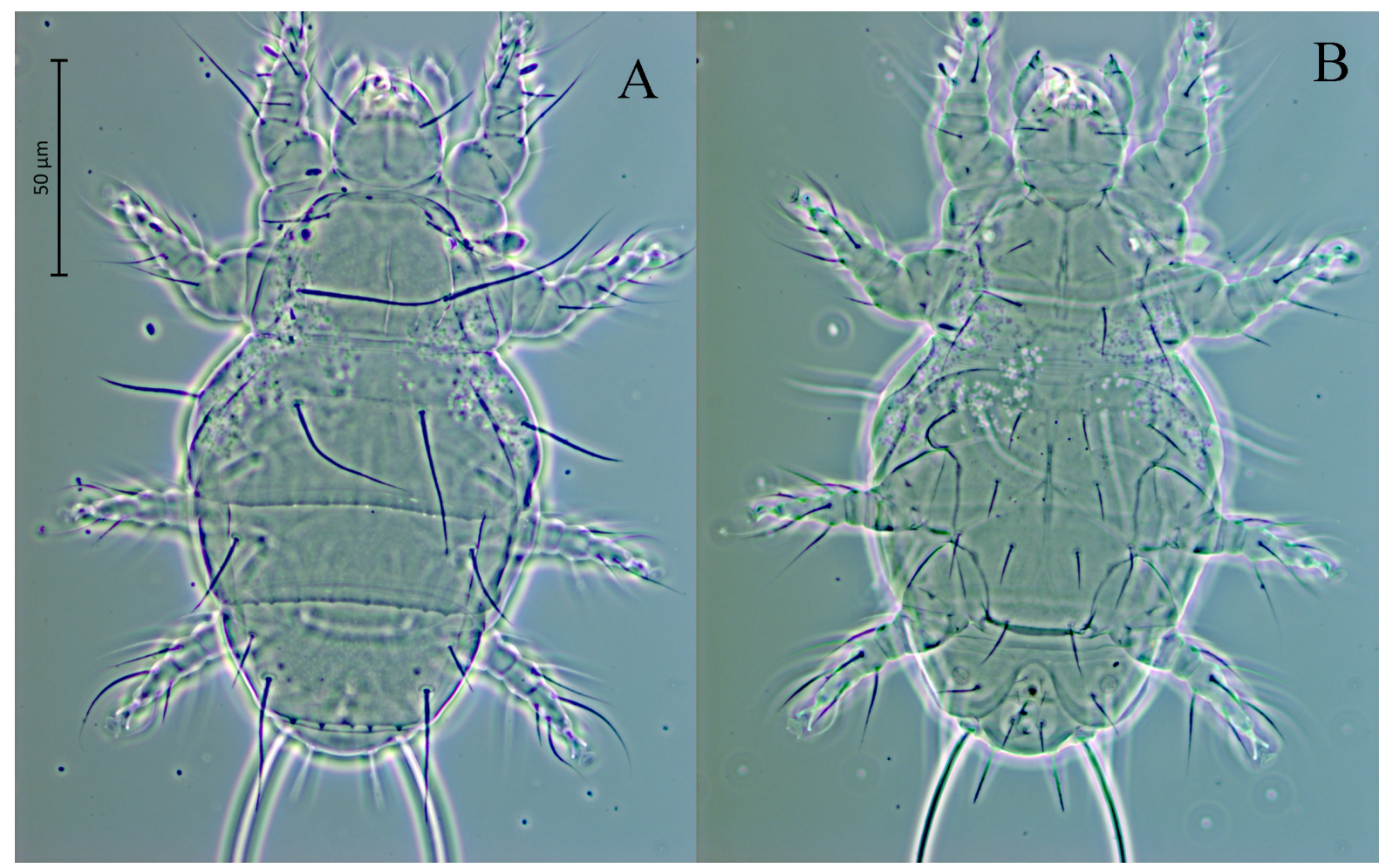

Fig. 4. Phase-contrast photomicrographs of Pavania foliata sp.n., female (holotype): A—dorsal view, B—ventral view.

Male unknown.

Type material. Female holotype, slide No. ZISP T-Dol-002, Russia, Astrakhan Province, Dosang locality, $46^{\circ} 54^{\prime} 56^{\prime \prime} \mathrm{N}, 047^{\circ} 55^{\prime} 04^{\prime \prime} \mathrm{E}, 12-14$ July 2020, A. V. Frolov leg. on beetles of Scarabaeus typhon attracted to fresh horse dung and collected manually. Paratypes: 9 females, same data.

Type deposition. The holotype and two paratypes are deposited in the collection of the Zoological Institute of RAS, Saint Petersburg, Russia; other paratypes are deposited in the collection of the Tyumen State University Museum of Zoology, Tyumen, Russia.

Differential diagnosis. The new species is most similar to Pavania lanceolata Bahramian and Hajiqanbar, 2015 in the presence of distinctly foliate setae $(u),(p v)$ on tarsus I and $u$ ' and $(p v)$ on tarsus II. The new species differs from $P$. lanceolata in: 1) having seta $t c$ " of tarsus II not modified (vs. foliate),2) setae $c_{1}$ being distinctly longer than $c_{2}$ (vs. $c_{1}$ being distinctly shorter than $c_{2}$ ), and 3 ) setae $2 c$ being clearly longer than $2 b$ (vs. setae $2 b$ and $2 c$ being subequal in length).

Etymology. The name of the new species is derived from Latin foliata, meaning foliate and refers to the presence of foliate setae on the legs.

Remarks. The host beetles belong to a large Palearctic/Paleotropic genus of dung beetles,
Scarabaeus Linnaeus. The adults of all species feed on herbivore dung. The larvae live in and feed on the brood balls, which the adults roll out of dung and bury in the soil. A few species of Scarabaeus, mostly from Iran, are known as hosts of Pavania spp. Pavania fusiformis Lombardini was described from Scarabaeus sacer Linnaeus from Tortona, Italy (Lombardini 1949). Pavania kamalii Hajiqanbar and Khaustov was described from Scarabaeus sp. from North Khorasan Province, Iran (Hajiqanbar and Khaustov 2010). Pavania lanceolata Bahramian and Hajiqanbar was described from Scarabaeus pius (Illiger) from Southern Isfahan Province, Iran (Bahramian et al. 2015). Pavania scarabaeophilus Hajiqanbar, Khaustov and Mortazavi was described from Scarabaeus sp. from Kerman Province, southern Iran (Hajiqanbar, Khaustov and Mortazavi 2019). Scarabaeus typhon is recorded for the first time as a host of Pavania and heterostigmatic mites.

\section{Key to world species of Pavania (based on Khaustov and Frolov 2020)}

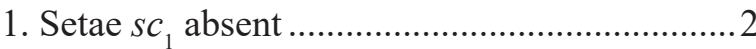

- Setae $s c_{1}$ present .............................................. 9

2. Setae $2 b$ present ............................................. 5

- Setae $2 b$ absent............................................... 3

3. Setae $1 c$ present, seta $d$ of femur IV absent .... 4 
- Setae $1 c$ absent, seta $d$ of femur IV present ..... .............. neotropica Khaustov and Frolov, 2017 (Brazil)

4. Seta $d$ of femur III present; setae $d$ pointed, distinctly longer than $c_{2}$.....

P. semireducta Khaustov and Frolov, 2020 (French Guiana)

- Seta $d$ of femur III absent; setae $d$ blunt-ended, distinctly shorter than $c_{2}$

P. brevicaudata Khaustov and Frolov, 2020 (French Guiana)

5. Seta $d$ absent on each femora III and IV .........6

- Seta $d$ present on each femora III and IV....... 7

6. All dorsal setae blunt-ended; setae $c_{2}$ only slightly longer than $c_{1}$ P. pusilla Khaustov and Frolov, 2020

(French Guiana)

- Setae $s c_{2}, c_{2}$ and $d$ pointed; setae $c_{2}$ about three times longer than $c_{1}$

....... P. hansreiaphila Khaustov and Frolov, 2020 (French Guiana)

7. Setae $v_{1}$ shorter than distance between their bases; setae cha less than three times longer than chb; setae $e$ never longer than $f$; setae $h_{2}$ at most

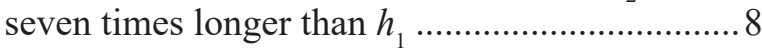

- Setae $v_{1}$ longer than distance between their bases; setae cha three times longer than $c h b$; setae $e$ longer than $f$; setae $h_{2} 15$ times longer than $h_{1} \ldots$ ...P. gymnopleuri Hajiqanbar and Khaustov, 2010 (Iran)

8. Genu I with one seta $\left(v^{\prime}\right)$; dorsal idiosomal setae smooth; setae $c_{1}$ longer than $c_{2}$; setae $c_{1}$ and $d$ pointed...P. sabzevarensis Hajiqanbar and Khaustov, 2010 (Iran)

- Genu I with two setae ( $\left.v^{\prime}, l^{\prime}\right)$; dorsal idiosomal setae weakly barbed; setae $c_{2}$ longer than $c_{1}$; setae $c_{1}$ and $d$ distinctly blunt-ended

.....P. onthophagi Hajiqanbar and Khaustov, 2010 (Iran)

9. Setae $s c_{1}$ capitate

- Setae $s c_{1}$ seta-like

...... P. setiformis Loghmani and Hajiqanbar, 2013 (Iran)

10. Setae $(u)$ and $(p v)$ of tarsus I not lanceolate ....14

- Setae $(u)$ and $(p v)$ of tarsus I lanceolate....... 11

11. Seta $p v$ " of tarsus III lanceolate.................... 12

— Seta $p v$ " of tarsus III not modified................ 13

12. Seta $t c$ " of tarsus II lanceolate, setae $c_{2}$ distinctly longer than $c_{1}$

....P. lanceolata Bahramian and Hajiqanbar, 2015 (Iran)

- Seta $t c$ " of tarsus II not modified, setae $c_{1}$ distinctly longer than $c_{2}$

P. foliata sp.n.
13. Setae $c_{1}, c_{2}$ and $d$ pointed; setae $2 c$ distinctly longer than $2 a$........... . kermaniensis Hajiqanbar, Khaustov and Mortazavi, 2019 (Iran)

- Setae $c_{1}, c_{2}$ and $d$ blunt-ended; setae $2 c$ and $2 a$ subequal ............. P. scarabaeophilus Hajiqanbar, Khaustov and Mortazavi, 2019 (Iran)

14. Coxal fields II with 3 pairs of setae 15

- Coxal fields II with 2 pairs of setae P. equisetosa Mahunka, 1975 (Ghana)

15. Empodium on tarsi II-IV small, not reaching beyond tips of claws. .16

— Empodium on tarsi II-IV large, reaching beyond tips of claws

16. Seta $p v$ ' on tarsi III and IV thickened, spiniform and blunt-ended, solenidia on tibiae III and IV absent P. protracta Sevastianov, 1980 (Russia)

- Seta $p v^{\prime}$ on tarsi III and IV simple, solenidia on tibiae III and IV present

......P. tahanae Sevastianov and Abo-Korah, 1985 (Egypt)

17. Setae $h_{2}$ less than 3.5 times longer than $h_{1} \ldots .18$ - Setae $h_{2}$ more than 3.5 times longer than $h_{1} \ldots . .23$ 18. Setae $c_{1}$ never reaching beyond bases of setae $f$; setae $c_{1}$ shorter than $h_{2}$; setae $d$ shorter than $h_{2} \ldots 19$ - Setae $c_{1}$ reaching beyond bases of setae $f$; setae $c_{1}$ longer than $h_{2}$; setae $d$ and $h_{2}$ subequal

P. perhirsuta Mahunka, 1973 (Ghana)

19. Setae $s c_{2}$ subequal to distance between their bases

- Setae $s c_{2}$ distinctly longer than distance between their bases. .20

20. Setae $h_{2}$ more than twice longer than $h_{1}$; posterior margins of tergites $\mathrm{C}, \mathrm{D}$ and $\mathrm{EF}$ with distinct toothshaped projections............. P. luisiae Mahunka, 1974 (Ghana)

- Setae $h_{2}$ less than twice longer than $h_{1}$; posterior margins of tergites $\mathrm{C}, \mathrm{D}$ and $\mathrm{EF}$ with very weak projections............... megasolenidia Hajiqanbar, Khaustov and Mortazavi, 2019 (Iran)

21. Setae $c_{1}, d, e$ and $f$ blunt-ended. 22

- Setae $c_{1}, d, e$ and $f$ pointed

P. bembidii Khaustov, 2005

(Russia: Crimea)

22. Setae $h_{1}$ almost three times longer than $p s$, solenidion $\varphi_{2}$ with rounded tip..... P. carabidophila Khaustov, 2005

(Russia: Krasnodar Territory, Primorye Territory)

- Setae $h_{1}$ almost subequal with $p s$, solenidion $\varphi_{2}$ with attenuated tip

..P. africana Khaustov and Frolov, 2018

(South Africa) 
23. Setae $h_{2}$ more than six times longer than $h_{1} \ldots . .24$

- Setae $h_{2}$ less than six times longer than $h_{1} \ldots 27$

24. Setae $s c_{2}$ less than 2.5 times longer than $v_{1}$; setae $f$ less than twice as long as $e$; setae $e$ shorter than $v_{1}$ ...25

- Setae $s c_{2}$ at least 3.5 times longer than $v_{1}$; setae $f$ more than twice as long as $e$; setae $e$ longer than $v_{1}$............................. endroedyi Mahunka, 1975 (Ghana)

25. Setae $s c_{2}$ more than twice as long as $v_{1}$; setae $f$ and $d$ subequal; setae $c_{1}$ never reaching beyond posterior border of tergite $C$. ....26 - Setae $s c_{2}$ less than twice as long as $v_{1}$; setae $f$ longer than $d$; setae $c_{1}$ reaching beyond posterior border of tergite C................. P. brasiliensis Mahunka, 1970 (Brazil)

26. Setae $2 a$ as long as $2 c$ and both longer than $c_{1}$, $d$ and $f$; setae $m$ protruding beyond anterior border of gnathosoma

........P. elongata Hajiqanbar and Khaustov, 2010 (Iran)

- Setae $2 a$ longer than $2 c$ and both shorter than $c_{1}, d$ and $f$; setae $m$ never protruding beyond anterior border of gnathosoma. 27

27. Setae $c_{1}, d$ and $f$ subequal and shorter than $c_{2} \ldots$ (Australia)

- Setae $c_{1}, d, f$ and $c_{2}$ subequal .. P. simplex Mahunka, 1973 (Ghana)

28. Empodium on tarsus I with rounded anterior margin; solenidia on tibiae III and IV absent....29 — Empodium on tarsus I with 3 lobes; tibiae III and IV with tiny solenidion...P. magowskii Hajiqanbar, Khaustov and Mortazavi, 2019 (Iran)

29. Setae $f$ distinctly longer than $e$; setae $e$ and $h_{1}$ subequal 30 - Setae $e$ and $f$ subequal; setae $e$ longer than $h_{1}$.. ....................... . tadjikistanica Sevastianov, 1980 (Tadjikistan, Iran)

30. Setae $2 c$ subequal with $2 a$... 32

- Setae $2 c$ about two times longer than $2 a$..... 31

31. Setae $c_{1}$ distinctly longer than $c_{2}$; setae $c h b$ blunt-ended ..............P. riparia Sevastianov, 1980 (Ukraine, Slovakia)

- Setae $c_{1}$ and $c_{2}$ subequal; setae $c h b$ pointed...... ............... P. copridis Khaustov and Frolov, 2020 (Borneo island)

32. Setae $f$ more than two times longer than $e$.... 33

- Setae $f$ less than 1.5 times longer than $e$ P. khiavensis Sobhi and Hajiqanbar, 2017 (Iran)

33. Most dorsal idiosomal setae weakly barbed and blunt-ended; setae $c_{1}$ longer than $c_{2}$; setae $s c_{2}$ less than twice as long as $c_{1}$

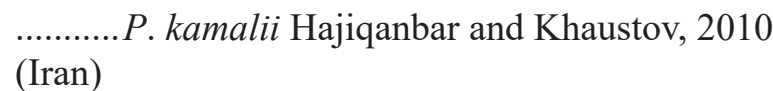

- Dorsal idiosomal setae smooth and pointed; setae $c_{2}$ longer than $c_{1}$; setae $s c_{2}$ more than twice as long as $c_{1}$.........P. fusiformis Lombardini, 1949 (Italy, Iran)

\section{ACKNOWLEDGEMENTS}

The study was supported by the Russian Foundation for Basic Research (RFBR), research project No. 18-04-01092A. The study of the junior author was performed in the framework of the state research project AAAA-A19-119020690101-6.

\section{REFERENCES}

Bahramian, M., Hajiqanbar, H. and Talebi, A.A. 2015. Two heterostigmatic mite species (Acari: Dolichocybidae, Podapolipidae) associated with Scarabaeus pius (Coleoptera: Scarabaeidae) from Iran. Acta Zoologica Academiae Scientiarum Hungaricae, 61: 25-32.

Grandjean, F. 1944. Observations sur les Acariens de la famille des Stigmaeidae. Archives des Sciences Physiques et Naturelles, 26: 103-131.

Hajiqanbar, H. and Khaustov, A.A. 2010. Anew species group and five new species of the genus Pavania (Acari: Dolichocybidae) associated with insects, with notes on leg chaetotaxy and the distribution of genera. European Journal of Entomology, 107: 441-453.

Hajiqanbar, H., Khaustov, A. and Mortazavi, A. 2019. New species of the genera Dolichocybe and Pavania (Acari: Dolichocybidae), phoretic on scarab beetles (Coleoptera: Scarabaeidae) from Iran. Systematic and Applied Acarology, 24(8): 1363-1382.

Kaliszewski, M., Athias-Binche, F. and Lindquist, E.E. 1995. Parasitism and parasitoidism in Tarsonemina (Acari: Heterostigmata) and evolutionary considerations. Advances in Parasitology, 35: 335-367.

Katlav, A., Hajiqanbar, H. and Talebi, A. A. 2014. First record of the genus Acanthomastix Mahunka, 1972 (Acari: Dolichocybidae) from Asia, with the description of a new species. International Journal of Acarology, 40: 7-14.

Katlav, A., Riegler, M. and Seeman, O.D. 2020. Tiny hitchhikers and parasites: a review of Australian heterostigmatic mites (Acari: Prostigmata) associated with insects, with description of three new species. Austral Entomology, 59: 401-421.

Khaustov,A.A. 2005. [Two new mite species of the genus Pavania (Heterostigmata, Dolichocybidae) from the Crimea and southern European Russia]. Zoologicheskiy Zhurnal, 84: 1515-1521. [In Russian] 
Khaustov, A.A. 2017. A new species of Dolichocybe (Acari: Dolichocybidae) from Western Siberia, Russia. Systematic and Applied Acarology, 22: 1678-1687.

Khaustov, A.A. and Frolov, A.V. 2017. New species of heterostigmatic mites (Acari: Heterostigmata: Athyreacaridae, Dolichocybidae, Pygmephoridae) associated with scarab beetles (Coleoptera: Geotrupidae, Scarabaeidae) from Brazil. Zootaxa, 4294: 501-521.

Khaustov, A. A. and Frolov, A. V. 2018a. A new species of Formicomotes Sevastianov (Acari: Heterostigmata: Dolichocybidae) associated with termites (Isoptera: Termitidae) from Brazil, with redescription of Formicomotes octipes Sevastianov, 1980. Zootaxa, 4382: 393-400.

Khaustov, A.A. and Frolov, A.V. 2018b. A new species of Pavania (Acari: Heterostigmata: Dolichocybidae) associated with Frankenbergerius gomesi (Coleoptera: Scarabaeidae) from South Africa. Acarina, 26(1): 133-140.

Khaustov, A.A. and Frolov, A. V. 2020. Five new species of Pavania (Acari: Heterostigmata: Dolichocybidae) phoretic on scarab beetles (Coleoptera: Scarabaeidae) from French Guiana and Malaysia. Systematic and Applied Acarology, 25(4): 707-727.

Khaustov, A.A. and Trach V.A. 2017. On the phoresy and morphology of Pavania carabidophila Khaustov, 2005 (Acari: Dolichocybidae). Acarina, 25(1), 25-28.

Khaustov, A.A. and Trach, V.A. 2018. Revision of the family Dolichocybidae (Acari: Heterostigmata) from the collection of V.D. Sevastianov. Acarologia, 58(4): 897-918.

Lan, Q., Lu, Zh., Ke, B., Liao, J., and Fan, Q.-H. 2017. Temperature and humidity effects on physogastric development and reproduction of the mushroom mite Dolichocybe perniciosa (Acari: Dolichocybidae). Systematic and Applied Acarology, 22(11): 1843-1848.

Lindquist, E.E. 1986. The world genera of Tarsonemidae (Acari: Heterostigmata): a morphological, phylogenetic, and systematic revision, with a reclassification of family-group taxa in the Heterostigmata. Memoirs of Entomological Society of Canada, 118: 1-517.

Loghmani, A., Hajiqanbar, H. and Talebi, A. 2013. A new species group and species of the genus Pavania (Acari: Dolichocybidae), phoretic on Onthophagus vitulus (Coleoptera: Scarabaeidae) from Iran. Zootaxa, 3693: 320-328.

Lombardini, G. 1949. Acari Nuovi. Redia, 34: 67-74.

Magowski, W.Ł. 1988. Description of a new species of Formicomotes Sevastianov, 1980 (Acari: Dolichocybidae) with notes on the female dimorphism within this genus. Mitteilungen aus dem Hamburgischen Zoologischen Museum und Institut, 85: 163-182.

Mortazavi, A., Hajiqanbar, H. and Kamali, K. 2015. A new species of the family Dolichocybidae Mahunka, 1970 (Acari: Heterostigmata) associated with Sinoxylon pugnax Lesne (Coleoptera: Bostrichidae) from Iran. Systematic and Applied Acarology, 20: 441-448.

Rahiminejad, V., Hajiqanbar, H. and Fathipour, Y. 2011. Redefinition of the genus Dolichocybe (Acari: Dolichocybidae), with description of two new species associated with insects. Annals of the Entomological Society of America, 104: 627-635.

Rack, V.G. 1967. Untersuchungen über die biologie von Dolichocybe Krantz, 1957 und beschreibung von zwei neuen Arten (Acarina, Pyemotidae). Mitteilungen aus dem Hamburgischen Zoologischen Museum und Institut, 64: 29-42.

Sevastianov, V.D. 1980. [New taxa of mites of the family Dolichocybidae (Trombidiformes, Tarsonemina) and phylogenetic relations of its subfamilies]. Zoologicheskiy Zhurnal, 59: 1453-1462. [In Russian]

Sobhi, M., Hajiqanbar, H. and Mortazavi, A. 2017. New species and records of heterostigmatic mites (Acari: Prostigmata: Heterostigmata) phoretic on scarabaeid dung beetles (Coleoptera: Scarabaeidae) from northwestern Iran. Zootaxa, 4276: 427-434. 